\title{
Liter per Millimole per Minute
}

National Cancer Institute

\section{Source}

National Cancer Institute. Liter per Millimole per Minute. NCI Thesaurus. Code C85678.

Liters per millimole per minute. 